\title{
PENERAPAN MODEL PEMBELAJARAN STAD DENGAN MEDIA TEKA-TEKI SILANG DAN MODEL PEMBELAJARAN DISCOVERY LEARNING KONSEP SISTEM GERAK PADA MANUSIA UNTUK MENINGKATKAN HASIL BELAJAR SISWA KELAS VIII SMP NEGERI 1 AMBON
}

\author{
Yuliana A. Maselkosu1, D. Rumahlatu², S.I.A. Salmanu² \\ ${ }^{1}$ Alumni Program Studi Pendidikan Biologi \\ 2Dosen Program Studi Pendidikan Biologi \\ E-mail : yuliana10814@gmail.com
}

\begin{abstract}
Background: The STAD model is to motivate students to support each other and help one another in mastering the abilities taught by the teacher. Crosswords are a game of sharpening the brain where we have to fill in the blank spaces (in the form of white boxes) with the letters that form a word based on the instructions given.

Method: Design of experimental research with the type of research used is descriptive comparative. The research subjects were the eighth grade students of Ambon 1 Junior High School, totaling 26 students. The instruments used were initial test and final test questions, observation sheets, student worksheets and group worksheets.

Results: Research shows that the application of the STAD Cooperative type learning model with Cross Puzzle media can improve student learning outcomes. On average all aspects of value have increased. Can be seen in the achievement of the estimated student score of $83.46 \%$. Continued hypothesis testing using the t-test with the value of thit> ttab $(2.27>2.01)$ thus there are differences in the improvement of student learning outcomes using the STAD type cooperative learning model with a crossword puzzle media.

Conclusion: There are differences in the application of the STAD learning model with crossword media and discovery learning learning models of motion systems concepts in humans to improve learning outcomes of class VIII students of SMPN 1 Ambon, it is evident that the results of t-test analysis where $t$ count> $t$ table that the STAD model with media crossword puzzles is more effective for improving student learning outcomes than the Discovery Learning model.
\end{abstract}

Keywords: Learning outcomes, motion systems, stad, crossword puzzles

\begin{abstract}
Abstrak
Latar Belakang: Model STAD adalah untuk memotivasi siswa dapat saling mendukung dan membantu satu sama lain dalam menguasai kemampuan yang diajarkan oleh guru. Teka-teki silang adalah suatu permainan mengasah otak dimana kita harus mengisi ruang-ruang kosong (berbentuk kotak putih) dengan huruf-huruf yang membentuk sebuah kata berdasarkan petunjuk yang diberikan. Metode: Desain penelitian eksperimen dengan tipe penelitian yang digunakan adalah deskriptif komparatif. Subjek penelitian adalah siswa kelas VIII SMPN 1 Ambon yang berjumlah 26 siswa. Instrumen yang digunakan adalah soal tes awal dan tes ahkir, lembar observasi, lembar kerja siswa dan lembar kerja kelompok.

Hasil: Penelitian menunjukkan bahwa penerapan model pembelajaran Kooperatif tipe STAD dengan media Teka Teki Silang dapat meningkatkan hasil belajar siswa. Rata-rata semua aspek nilai mengalami peningkatan. Dapat dilihat pada pencapaian nilai ahkir siswa $83,46 \%$. Dilanjutkan uji hipotesis menggunakan Uji-t dengan nilai thit $>$ tab $(2,27>2,01)$. Terdapat perbedaan peningkaatan hasil belajar siswa menggunakan model pembelajaran kooperatif tipe STAD dengan media teka teki silang. Kesimpulan: Terdapat perbedaan penerapan model pembelajaran STAD dengan media teka-teki silang dan model pembelajaran discovery learning konsep sistem gerak pada manusia untuk meningkatkan hasil belajar siswa kelas VIII SMPN 1 Ambon, terbukti bahwa pada hasil analisis uji-t dimana thitung $>$ tabel sehingga dapat dikatan bahwa model STAD dengan media teka-teki silang lebih efektif untuk meningkatkan hasil belajar siswa dari pada model Discovery Learning.
\end{abstract}

Kata Kunci: Hasil belajar, sistem gerak, stad, teka-teki silang.

Yuliana. A. Maselkosu, D. Rumahlatu, S.I.A. Salmanu, Penerapan Model Pembelajaran ... 70 


\section{PENDAHULUAN}

Pendidikan adalah proses seseorang mengembangkan kemampuan, sikap dan tingkah laku, sehingga dapat mengalami perkembangan kemampuan sosial dan kemampuan individu yang optimal. Kualitas pendidikan yang baik tidak terlepas dari pelaksanaan pendidikan yang efektif (Kulsum, 2013). Pembelajaran sains memiliki komponen dasar yang tidak dapat dipisahkan yaitu produk dan proses. Selaras dengan hakikat IPA sebagai sains, maka pembelajaran IPA seharusnya mengembangkan keterampilan berpikir dan keterampilan praktik. Kedua keterampilan tersebut diperlukan untuk mengembangkan pengalaman belajar siswa. Pengalaman belajar siswa dalam pembelajaran IPA dapat diperoleh melalui keterampilan proses sains (Prayitno, 2010). Pemilihan STAD dikarenakan model ini mampu memfasilitasi kebutuhan belajar siswa yang memiliki tingkat akademik berbeda. Penerapan model STAD diharapkan dapat membantu siswa untuk saling bekerja sama dengan anggota kelompok dalam mempelajari materi yang diberikan guru. Adanya kegiatan diskusi menyebabkan siswa yang lebih pandai dapat membantu siswa yang kurang pandai. Dengan demikian siswa yang memiliki keterbatasan dalam belajar dapat terbantu dalam memahami materi yang nantinya akan dijadikan sebagai bahan untuk kuis individual.

Media pembelajaran merupakan segala sesuatu yang dapat menyampaikan dan menyalurkan pesan dari sumber secara terencana sehingga tercipta lingkungan belajar yang kondusif dimana penerimanya dapat melakukan proses belajar secara efisien dan efektif (Munadi, 2008).

Model discovery learning adalah belajar penemuan (discovery learning) merupakan salah satu model pembelajaran kognitif yang dikembangkan oleh Bruner (1966). Belajar penemuan adalah proses belajar dimana guru harus menciptakan situasi belajar yang problematis, menstimulus siswa dengan pertanyaan-pertanyaan, mendorong siswa mencari jawaban sendiri, dan melakukan eksperimen. Belajar penemuan pada akhirnya dapat meningkatkan penalaran dan kemampuan untuk berpikir secara bebas dan melatih keterampilan kognitif siswa dengan cara menemukan dan memecahkan masalah yang ditemui dengan pengetahuan yang telah dimiliki dan menghasilkan pengetahuan yang benar-benar bermakna bagi dirinya.

Hasil observasi dengan guru mata pelajaran IPA kelas VIII di SMP Negeri 1 Ambon, maka ada beberapa masalah yang ditemui bahwa siswa mempunyai gaya belajar yang berbeda-beda pada masingmasing siswa karena itu para siswa belum mempunyai motivasi yang tinggi untuk belajar. KKM mata pelajaran IPA 67 dan belum mampu memahami materi tentang sistem gerak pada manusia. Pada saat proses pembelajaran IPA, terlihat bahwa siswa tidak terlalu antusias mengikutinya. Maka sebagai guru yang kreatif dan inovatif haruslah mampu menggunakan model dan media yang tepat dalam mengelola pembelajaran yang berkualitas dan menyenangkan untuk memperlancar pencapaian dan variasi baru bagi pengalaman belajar peserta didik sehingga peserta didik tidak bosan dan hasil belajar yang diperoleh peserta didik dapat optimal.

\section{MATERI DAN METODE}

Jenis penelitian yang digunakan dalam penelitian ini adalah jenis penelitian komparatif deskriptif, dengan menggunakan model STAD dengan media TTS dan model Discovery Learning. Penelitian ini dilakukan pada lokasi SMP Negeri 1 Ambon. Penelitian ini dilaksanakan mulai dari tanggal 12 Juli sampai dengan 12 Agustus 2017. Populasi yang digunakan dalam penelitian ini adalah semua siswa kelas VIII SMP Negeri 1 Ambon yang berjumlah 208 orang siswa. Sebagai sampel dari populasi yang ada, maka pengambilan sampel dilakukan pada 2 kelas yaitu kelas $\mathrm{VIII}^{5}$ berjumlah 26 orang dan $\mathrm{VIII}^{6}$ berjumlah 26 orang dengan demikian siswa yang ditetapkan sebagai sampel dalam penelitian ini berjumlah 52 orang. Rancangan dalam penelitian ini adalah Kepustakaan, mengumpulkan sejumlah literature yang relevan dengan masalah dalam penelitian. Observasi, merupakan cara pengumpulan data dengan pengamatan secara langsung terhadap proses belajar. Dengan menggunakan test hasil belajar siswa 
berdasarkan instrument penelitian yang dilakukan setelah menyelesaikan pengajaran pada konsep sistem gerak pada manusia pada kelas model pembelajaran STAD dengan madia Teka-teki silang dan kelas model pembelajaran discovery learning.

Teknik analisis data yang digunakan adalah analisis deskriptif. Kemudian data yang di peroleh dari penelitian ini kemudian diolah dengan menggunakan analisis data deskriptif setelah data terkumpul dari hasil penelitian, kemudian dilakukan untuk menjawab hipotesis dengan cara sebagai berikut.

1. Untuk hasil tes butir soal atau tes formatif (aspek kognitif) skor pencapaian diperoleh dengan menggunakan rumus:

4. Untuk nilai proses (NP) diperoleh dengan rumus:

$N P=\frac{\text { pencapaian kognitif }+ \text { pencapaian a fektif }+ \text { pencapaian psikomotor }}{3}$

Untuk memperoleh nilai akhir (NA) baik hasil maupun proses di peroleh dengan rumus:

Untuk menjawab apakah ada
perbedaan perlakuan antara model pembelajaran project based learning dan model pembelajaran discovery learning dilakukan Uji-t dengan rumus :

$$
\begin{aligned}
\mathrm{t} & =\frac{\bar{X} 1-\bar{X} 2}{S \sqrt{\frac{1}{n 1}}+\frac{1}{n 2}} \\
\mathrm{~S}^{2} & =\frac{\left(\mathrm{N}^{1}-\right) s \frac{1}{2}-\left(\mathrm{N}^{2}-1\right) s_{2}^{2}}{\mathrm{n}^{2}-\mathrm{n}^{2}-2}
\end{aligned}
$$

Keterangan:

$\bar{X} 1$ : rata-rata hasil belajar kelas STAD dengan media Teka-teki silang

$\bar{X} 2$ : rata-rata hasil belajar kelas Discovery Learning

$\mathrm{n} 1$ : jumlah siswa kelas STAD dengan media Teka-teki silang

n2 : jumlah siswa kelas Discovery Learning

$S_{1}^{2}$ : Simpangan baku kelas STAD dengan media Teka- teki silang

$S_{2}^{2}$ : Simpangan kelas Discovery learning

Dengan kriterian ada perbedaan hasil belajar, jika
Skor pencapaian $=\frac{\text { skor perolehan }}{\text { skor maksimum }} \times 100 \%$

2. Untuk hasil observasi pada aspek afektif di peroleh dari lembar kerja siswa, dimana siswa dibagi atas beberapa kelompok. Kemudian LKS di bagikan untuk di kerjakan dalam kelompok. Peneliti memberikan nilai sesuai dengan skor yang telah di tentukan. Proses penilaian pada LKS dengan rumus :

Skor pencapaian $=\frac{\text { skor perolehan }}{\text { skor maksimum }} \times 100 \%$

3. Untuk hasil observasi pada aspek psikomotor, skor pencapaian diperoleh dengan rumus:

Skor pencapaian $=\frac{\text { skor perolehan }}{\text { skor maksimum }} \times 100 \%$

$\mathrm{NA}=\frac{6 P+4 F}{10}$

Keterangan:

NA : Nilai Akhir

$P$ : Nilai Proses

$\mathrm{F}$ : Nilai hasil tes formatif setelah proses pembelajaran

Ha jika $t_{\text {hit }}>$ dari $t_{\text {tab }}$

Ho jika $t_{\text {hit }}<$ dari $t_{\text {tab }}$

Untuk menghitung rata-rata maka menggunakan rumus :

$\bar{X}=\frac{\sum x 1}{n}$

Dimana :

$\bar{X}=$ rata-rata hitung

$\sum x 1=$ jumlah total nilai siswa

$\mathrm{n}=$ jumlah sampel

\section{HASIL DAN PEMBAHASAN}

Berdasarkan hasil penelitian perbedaan hasil belajar siswa dengan menggunkan model pembelajaran STAD dengan Media Teka-teki silang dan model pembelajaran discovery learning konsep sistem gerak pada manusia untuk kelas VIII SMP Negeri 1 Ambon. Penilaian peningkatan hasil belajar dilakukan dengan penilaian formatif dan nilai proses Kegiatan Belajar Mengajar (KBM), yaitu: 
Tes Awal

\begin{tabular}{|c|c|c|c|c|c|c|}
\hline \multicolumn{3}{|c|}{$\begin{array}{c}\text { Kelas STAD dengan } \\
\text { media teka-teki silang }\end{array}$} & \multirow{2}{*}{ Klasifikasi } & \multicolumn{2}{|c|}{$\begin{array}{c}\text { Kelas Discovery } \\
\text { Learning }\end{array}$} & \multirow{2}{*}{ Klasifikasi } \\
\hline Interval & Frekuensi & Presentase & & Frekuensi & Presentase & \\
\hline $\begin{array}{l}>67 \\
<67\end{array}$ & $\begin{array}{c}3 \\
23\end{array}$ & $\begin{array}{l}11,54 \% \\
88,46 \%\end{array}$ & $\begin{array}{l}\text { Tuntas } \\
\text { Gagal }\end{array}$ & $\begin{array}{c}2 \\
24\end{array}$ & $\begin{array}{l}7,70 \% \\
92,30 \%\end{array}$ & $\begin{array}{l}\text { Tuntas } \\
\text { Gagal }\end{array}$ \\
\hline Jumlah & 26 & $100 \%$ & & 26 & $100 \%$ & \\
\hline
\end{tabular}

Berdasarkan tabel 1. diatas maka hasil tes awal siswa untuk kelas STAD dengan media TTS terdapat 3 orang siswa $(11,54 \%)$ memperoleh nilai pada interval (> 67) dengan klasifikasi tuntas dan 23 orang siswa $(88,46 \%)$ memperoleh nilai pada interval $(<67)$ dengan klasifikasi gagal sedangkan untuk kelas Discovery Learning terdapat 2 orang siswa $(7,70 \%)$ klasifikasi tuntas dan 24 orang siswa $(92,30 \%)$ klasifikasi gagal. Hal ini sejalan dengan penelitian (Nernia, 2007) bahwa hal ini wajar karena kedua kelas tersebut belum mendapatkan perlakuan dan materi ajar.

\section{Aspek Kognitif}

\begin{tabular}{|c|c|c|c|c|c|c|}
\hline \multicolumn{3}{|c|}{$\begin{array}{l}\text { Kelas STAD dengan } \\
\text { media teka-teki silang }\end{array}$} & \multicolumn{4}{|c|}{ Kelas Discovery } \\
\hline Interval & Frekuensi & Presentase & & Frekuensi & Presentase & Klasifikasi \\
\hline $\begin{array}{l}>67 \\
<67\end{array}$ & $\begin{array}{c}26 \\
-\end{array}$ & $\begin{array}{c}100 \% \\
-\end{array}$ & $\begin{array}{l}\text { Tuntas } \\
\text { Gagal }\end{array}$ & $\begin{array}{c}26 \\
-\end{array}$ & $\begin{array}{c}100 \% \\
-\end{array}$ & $\begin{array}{l}\text { Tuntas } \\
\text { Gagal }\end{array}$ \\
\hline Jumlah & 26 & $100 \%$ & & 26 & $100 \%$ & \\
\hline
\end{tabular}

Berdasarkan tabel 2 diatas maka, data hasil penilaian aspek kognitif siswa siswa untuk kelas STAD dengan media teka-teki silang terdapat 26 orang siswa $(100 \%)$ memperoleh nilai pada interval (>67) dengan klasifikasi tuntas. Sedangkan untuk siswa kelas Discovery Learning terdapat 26 orang siswa $(100 \%)$ memperoleh nilai (>67) dengan klasifikasi tuntas. Dengan demikian seluruh siswa pada kelas STAD dengan media teka-teki silang dan kelas Discovery Learning sangat baik sehingga sudah mampu menguasai indikator pembelajaran pada konsep yang di ajarkan yaitu sistem gerak manusia.

Aspek Afektif

\begin{tabular}{ccccccc}
\hline \multicolumn{2}{c}{$\begin{array}{c}\text { Kelas STAD dengan } \\
\text { media teka-teki silang }\end{array}$} & Klasifikasi & \multicolumn{2}{c}{$\begin{array}{c}\text { Kelas Discovery } \\
\text { Learning }\end{array}$} & Klasifikasi \\
\cline { 3 - 6 } Interval & Frekuensi & Presentase & & Frekuensi & Presentase & \\
\hline$>67$ & 26 & $100 \%$ & Tuntas & 22 & $84,62 \%$ & Tuntas \\
$<67$ & - & - & Gagal & 4 & $15,38 \%$ & Gagal \\
\hline Jumlah & $\mathbf{2 6}$ & $\mathbf{1 0 0} \%$ & & $\mathbf{2 6}$ & $\mathbf{1 0 0} \%$ & \\
\hline
\end{tabular}

Berdasarkan tabel 3. diatas maka data hasil penelitian untuk kelas STAD dengan media teka-teki silang terdapat 26 orang siswa $(100 \%)$ memperoleh nilai pada interval (>67) dengan kualifikasi tuntas, sedangkan untuk kelas Discovery Learning
4 orang siswa $(15,38 \%)$ memperoleh nilai pada interval $(>67)$ dengan kualifikasi tuntas dan 22 orang siswa (84,62 \%) memperoleh nilai pada interval $(<67)$ dengan kualifikasi gagal. 
Aspek Psikomotor

\begin{tabular}{|c|c|c|c|c|c|c|}
\hline \multicolumn{3}{|c|}{$\begin{array}{l}\text { Kelas STAD dengan media teka- } \\
\text { teki silang }\end{array}$} & \multirow{2}{*}{ Klasifikasi } & \multicolumn{2}{|c|}{$\begin{array}{l}\text { Kelas Discovery } \\
\text { Learning }\end{array}$} & \multirow{2}{*}{ Klasifikasi } \\
\hline Interval & Frekuensi & Presentase & & Frekuensi & Presentase & \\
\hline $\begin{array}{l}>67 \\
<67\end{array}$ & $\begin{array}{c}26 \\
-\end{array}$ & $100 \%$ & $\begin{array}{l}\text { Tuntas } \\
\text { Gagal }\end{array}$ & $\begin{array}{c}26 \\
-\end{array}$ & $\begin{array}{c}100 \% \\
-\end{array}$ & $\begin{array}{l}\text { Tuntas } \\
\text { Gagal }\end{array}$ \\
\hline $\begin{array}{c}\text { Jumla } \\
\text { h }\end{array}$ & 26 & $100 \%$ & & 26 & $100 \%$ & \\
\hline
\end{tabular}

Berdasarkan tabel 4 diatas maka, data hasil penilaian aspek psikomotor siswa siswa untuk kelas STAD dengan media teka-teki silang terdapat 26 orang siswa (100 \%) memperoleh nilai pada interval (>67) dengan klasifikasi tuntas. Dan juga untuk siswa kelas Discovery Learning terdapat 26 orang siswa (100 \%) memperoleh nilai (>67) dengan klasifikasi tuntas.

Hal ini sejalan dengan pendapat (Moon, 2005) bahwa penilaian dalam kurilukum 2013 mempertegas adanya perbedaan penilaian seperti dari penilaian melalui tes (mengukur kompetensi pengetahuan berdasarkan hasil saja) menuju penilaian autentik (penilaian menyeluruh yaitu penilaian sikap, keterampilan, dan pengetahuan berdasarkan proses dan hasil. Penilaian autentik memiliki karakteristik sebagai berikut: (1) fokus pada materi yang penting, ide-ide besar atau kecakapan-kecakapan khusus, (2) merupakan penilaian yang mendalam, (3) mudah dilakukan di kelas atau di lingkungan sekolah, (4) menekankan pada kualitas produk atau kinerja dari pada jawaban tunggal (5) dapat mengembangkan kekuatan dan penguasaan materi pembelajaran pada siswa, (6) menyediakan banyak cara yang memungkinkan siswa dapat menunjukkan kemampuannya sebagai hasil belajar, dan (7) pemberian skor penilaian didasarkan pada esensi tugas.

Tes Ahkir

\begin{tabular}{|c|c|c|c|c|c|c|}
\hline \multicolumn{3}{|c|}{$\begin{array}{l}\text { Kelas STAD dengan } \\
\text { media teka-teki silang }\end{array}$} & \multicolumn{4}{|c|}{ Kelas Discovery } \\
\hline Interval & Frekuensi & Presentase & & Frekuensi & Presentase & Klasifikas \\
\hline $\begin{array}{l}>67 \\
<67\end{array}$ & $\begin{array}{c}26 \\
-\end{array}$ & $\begin{array}{c}100 \% \\
-\end{array}$ & $\begin{array}{l}\text { Tuntas } \\
\text { Gagal }\end{array}$ & $\begin{array}{c}26 \\
-\end{array}$ & $\begin{array}{c}100 \% \\
-\end{array}$ & $\begin{array}{l}\text { Tuntas } \\
\text { Gagal }\end{array}$ \\
\hline Jumlah & 26 & $100 \%$ & & 26 & $100 \%$ & \\
\hline
\end{tabular}

Berdasarkan tabel 5 diatas maka, hasil tes ahkir siswa bahwa pada kelas STAD dengan media teka-teki silang terdapat 26 orang siswa (100\%) memperoleh nilai pada interval (> 67) dengan kualifikasi tuntas, sedangkan untuk kelas Discovery Learning terdapat 26 orang siswa (100 \%) memperoleh nilai pada interval ( $>67$ ) dengan kualifikasi tuntas. Kualifikasi kelas STAD dengan media teka-teki silang dan kelas Discovery Learning sudah mencapai standar KKM untuk mata pelajaran IPA Biologi pada konsep sistem gerak manusia dengan nilai KKM adalah 67.
Dari arti kata form yang merupakan dasar dari istilah formatif maka evaluasi formatif dimaksudkan untuk mengetahui sejauh mana siswa telah terbentuk setelah mengikuti suatu program tertentu. Evaluasi atau tes formatif diberikan pada ahkir setiap program pembelajaran. Disekolah sering disamakan dengan ulangan harian, yaitu kegiatan yang dilakukan secara periodik untuk mengukur pencapaian kompetensi dasar. (Direktorat Pembinaan Sekolah Menengah Atas, 2008). 
Nilai Ahkir (NA)

\begin{tabular}{cccccccc}
\hline \multicolumn{2}{c}{$\begin{array}{c}\text { Kelas STAD dengan } \\
\text { media teka-teki silang }\end{array}$} & \multirow{2}{*}{ Klasifikasi } & \multicolumn{2}{c}{$\begin{array}{c}\text { Kelas Discovery } \\
\text { Learning }\end{array}$} & Klasifikasi \\
\cline { 6 - 7 } & Interval & Frekuensi & Presentase & & Frekuensi & Presentase & \\
\hline$>67$ & 26 & $100 \%$ & & Tuntas & 26 & $100 \%$ & Tuntas \\
$<67$ & - & - & Gagal & - & - & Gagal \\
\hline Jumlah & $\mathbf{2 6}$ & $\mathbf{1 0 0} \%$ & & $\mathbf{2 6}$ & $\mathbf{1 0 0} \%$ & \\
\hline
\end{tabular}

Berdasarkan tabel 6 diatas maka data hasil presentase nilai ahkir untuk masing masing kelas. Kelas STAD dengan media teka-teki silang terdapat 26 orang siswa (100 \%) memperoleh nilai pada interval (>
67) dengan kualifikasi tuntas, dan juga untuk kelas Discovery Learning terdapat 26 orang siswa (100\%) memperoleh nilai pada interval (> 67) dengan kualifikasi tuntas.

\section{Uji Hipotesis}

\begin{tabular}{|c|c|c|c|c|c|c|}
\hline Kelas & Variabel & $\mathbf{N}$ & Mean & SB & $\mathbf{t}$-hitung & $\mathbf{t}-$ tabel \\
\hline $\begin{array}{l}\text { Kelas } \\
\text { VIIII }\end{array}$ & $\begin{array}{c}\text { STAD } \\
\text { dengan } \\
\text { media teka- } \\
\text { teki silang }\end{array}$ & 26 & 82 & 1327 & 2,27 & 2,01 \\
\hline $\begin{array}{l}\text { Kelas } \\
\text { VIIII }\end{array}$ & $\begin{array}{l}\text { Discovery } \\
\text { Learning }\end{array}$ & 26 & 72,42 & 11443,35 & & \\
\hline
\end{tabular}

Berdasarkan tabel 7 diatas maka, mean dari skor hasil belajar siswa pada kelas metode STAD dengan media teka-teki silang lebih besar dari pada kelas Discovery Learning, hal ini menunjukan bahwa kamampuan hasil belajar siswa pada kelas metode STAD dengan media teka-teki silang lebih meningkat dari pada kelas Discovery Learning.

Untuk melihat dan menguji perbedaan hasil belajar dari siswa kelas metode STAD dengan media teka-teki silang maupun kelas Discovery Learning perlu dilakukan uji - $t$ dan perolehan hasil $t_{\text {hitung }}=2,27$ dan tabel 2,01 . Oleh karena $t_{\text {hitung }}>t_{t a b e l}$, sehingga memperlihatkan bahwa ada perbedaan yang signifikan dalam hasil belajar siswa materi sistem gerak pada manusia untuk siswa kelas VIII SMP Negeri 1 Ambon yang diajarkan dengan menggunakan model STAD dengan media teka-teki silang dan model Discovery Learning pada siswa SMP Negeri 1 Ambon.

Hal ini sejalan dengan Ekawati Sukandar (2015) bahwa hasil penelitiannya menunjukan terdapat perbedaan hasil belajar siswa antara yang menggunakan model pembelajaran STAD dengan model pembelajaran discovery learning, serta peningkatan hasil belajar siswa dengan menggunakan model pembelajaran STAD lebih tinggi dibandingkan dengan menggunakan model pembelajaran discovery learning. Hal ini sesuai dengan pendapat Sudjana dan Ahmad (2012) bahwa penggunaan media pembelajaran dapat mempertinggi hasil belajar yang dicapainya.

\section{KESIMPULAN}

Berdasarkan hasil penelitian dan pembahasan yang ada serta uji hipotesis maka dapat disimpulkan bahwa: Ada perbedaan penerapan model pembelajaran STAD dengan media teka-teki silang dan model pembelajaran discovery learning konsep sistem gerak pada manusia untuk meningkatkan hasil belajar siswa kelas VIII SMP Negeri 1 Ambon, terbukti bahwa pada hasil analisis $u j i-t$ dimana $t_{\text {hitung }}>t_{\text {tabel }}$ sehingga dapat dikatan bahwa model STAD dengan media teka-teki silang lebih efektif untuk meningkatkan hasil belajar siswa dari pada model Discovery Learning. 
DAFTAR PUSTAKA

Bruner, 1966. Penerapan Model Pembelajaran Discovery Learning Terhadap Hasil Belajar Siswa Kelas X TAV Pada Standar Kompetensi Melakukan Instalasi Sound System Di SMK Negeri 2 Surabaya. Jurnal Pendidikan Teknik Elektro, Volume 03, Nomor 01, Tahun 2014. Universitas Negeri Surabaya.

Ekawati Sukandar (2015) Perbandingan Model Pembelajaran Discovery Learning dengan Model Pembelajaran Kooperatif Tipe Student Teams Achievement Division (STAD) pada Mata Pelajaran Konstruksi Bangunan di SMKN 1 Sumedang. Depertemen Pendidikan Teknik Arsitektur, Fakultas Pendidikan Teknologi dan Kejuruan, Universitas Pendidikan Indonesia.

Direktorat Pembinaan Sekolah Menengah Atas, 2008. Analisis Kesesuaian Antara Instrumen Evaluasi Formatif Dengan Tujuan Koognitif Pembelajaran Biologi di SMP Watansoppeng. Hamka Lodang dan Nur Afni Suraya Baya. Jurnal Bionature, Volume 13,No 2, Oktober 2012.

Kulsum, 2013. Pengaruh Model Pembelajaran Kooperatif Tipe STAD Berbantuan Flipbook Terhadap Hasil Belajar Siswa SMP. Desi Rahmawati, Kurnia Ningsih, Eko Sri Wahyuni. Program Studi Pendidikan Biologi FKIP Untan, Pontianak. Artikel Penelitian.

Moon, 2005. Evaluasi Hasil Belajar Menggunakan Penilaian Autentik Pada Mata Pelajaran Kelistrikan Sistem Refrigerasi. Journal of Mechanical Engineering Education, Vol.1, No.2, Desember 2014

Munadi, 2008. Perbedaan Hasil Belajar Biologi Menggunakan Media Peta konsep Dan Teka-Teki Silang (TTS) Pokok Materi Dunia tumbuhan (Kingdom Plantae) Pada Siswa Kelas X SMA Negeri 1 Mojolaban Sukoharjo Tahun Ajaran 2012/2013

Nernia, 2007. Perbedaan Hasil Belajar Siswa Yang Diajar Dengan Model Pembalajaran Cooperatif Tipe Stay Two Stray (TSTS) dan Belajajar Dengan Tipe Teams Games Toutnament (TGT) Pada Siswa Kelas X di SMA Negeri 1 Wolowa. Jurnal
Penelitian Geografi Volume 1 No. 1 April 2007.

Prayitno, 2010. Penerapan Model Pembelajaran Kooperatif Tipe STAD Terhadap Keterampilan Proses Sains Siswa. Artikel, Riya Mariga Sari, Tri Jalmo, Berti Yolida. Universitas Lampung.

Sudjana dan Ahmad, 2012. Upayah Meningkatkan Hasil Belajar Ekonomi Melalui Penerapan Model Pembelajaran Kooperatif Tipe TGT Dengan Menggunakan Permainan Multimedia. Artikel Fakultas ekonomi, UNESA. Kelintang Surabaya. 